\title{
Banking union: the disadvantages of opportunism
}

\author{
David G. Mayes \\ Department of Accounting and Finance, University of Auckland, Auckland, New Zealand; ARENA, \\ University of Oslo, Oslo, Norway
}

\begin{abstract}
The EU's approach to what it describes as "banking union" is not what one would design with a clean slate. It reflects the political constraints and the path of history. This paper compares the institutional and operational structure of "banking union" that has been decided upon with a complete structure. It focuses on the distortions caused by a system based on the euro area, which excludes Europe's most important financial market. It considers the difficulties posed for the Single Resolution arrangements and the European Deposit Insurance System by the continuing problem of the relation between weak banks and over-indebted sovereigns.
\end{abstract}

\section{Keywords}

Banking union; Bail-in; deposit insurance; single supervisory mechanism; Volcker rule

In getting "banking union" into law between 2012 and 2014, the EU did a remarkable job. This has involved not merely the implementation of the new capital and other rules recommended by the Basel Committee on Banking Supervision and the Financial Stability Board (FSB) in a common framework ${ }^{1}$ but the establishment of the ECB as the over-riding supervisor for the euro area, with direct responsibility for the largest banks, the passing of the Bank Recovery and Resolution Directive (BRRD) ${ }^{2}$ and the setting up of the Single Resolution Board (SRB). ${ }^{3}$ This covers all sides of trying to preserve financial stability at the EU level in future: from problem avoidance and making the system more resilient to shocks, to supervision and early detection and then resolution of such problems that do get through - it is hoped without the use of taxpayer funds that characterised the response to the global financial crisis. ${ }^{4}$

However, making such rapid progress has come at a price. The new system is not neat and comprehensive. It has omissions, it has some inelegant features, and it is not clear how well it will work. ${ }^{5}$ It may also have contributed to breaking up rather than reinforcing the EU. The list of omissions and other problems is long but this paper draws attention to just two of them.

(1) The ECB's responsibility for financial supervision does not cover the whole of the EU nor indeed the whole of the financial sector. The Single Supervisory Mechanism (SSM) is thus a misnomer. At present, the exclusion of the UK with the most important financial sector and international banking system in Europe is particularly unfortunate. But even under Brexit, some accommodation is needed and the non-euro countries need to become equal members in the SSM. The contortion by which it is hoped to get round their lack of membership of the Governing Council is very much a second best. The SSM needs to be not just EU but EEA-wide if it is to work properly. The equation of the SSM and the euro area has nothing to do with the practicalities of banking supervision and the characteristics of maintaining financial stability. 
It is simply that this is all that invoking Art 127(6) of the TEU would allow. Implementing the full system would have required a treaty change and would not have been agreed by some countries including the UK. Waiting for the UK to leave the EU is not a solution.

(2) The full range of agreement is not yet complete. The draft directive imposing restraints on the structure of financial institutions to make them both more resilient and resolvable that was tabled in January $2014^{6}$ following the publication of the Liikanen Report ${ }^{7}$ has languished. Secondly, the single approach to deposit insurance is still in progress, but here there seem better prospects of an agreement. ${ }^{8}$ Some (e.g. Howarth and Quaglia 2014; 2016; Lastra 2016) have argued that a European level Lender of Last Resort is needed but this is heavily disputed so it is not covered in this paper. ${ }^{9}$

The immediate problem in making any progress on these issues is that having made such dramatic changes, there is likely to be little political appetite for going further unless some clear need is demonstrated, such as a failure of the new system to work as planned. That of course is the worst possible reason, and change without a crisis would be greatly preferable. The biggest concern is that the UK as the most important player is not part of the full regime, although it is a full participant in the "Single Rulebook" of common regulation and is subject to the BRRD. Without Brexit, keeping the UK in the EU might have involved some renegotiation of the treaty. But it seems highly unlikely that the negotiations on the terms of exit will include some completion of banking union, even though it is clear that the City of London would like to remain fully in the system. It is also not clear that having the UK leave the EU renders the problem of handling cross-border banks any easier. Obviously in the very long run, the discrepancy for non-euro area members would disappear if they join the euro area, but this would not apply to the non-EU EEA members such as Norway. Nor would it solve the other issues in making the system more effective. In part, therefore what follows is an agenda for what needs doing for when the opportunity arises.

There is a second political tension behind the current arrangements that will affect the plausibility of any neater solution. One motivation for "banking union" was that member states with high debt levels do not have the resources to bail out banks on the scale required in 2008/9. This was variously labelled a "doom loop", diabolic loop or simply a vicious circle (Gros and Schoenmaker 2014). Hence, those governments who feared that constraint sought a banking union that would enable a mutualisation of the losses. Those on the other hand that saw themselves as being on the paying rather than the receiving end of the arrangement, principally Germany, argued strongly for both limited mutualisation and strong preconditions - that all the banks were properly capitalised before the process started (Howarth and Quaglia 2013; 2014, 2016; Schäfer 2016). The BRRD/SRR was supposed to make the chance of using public funds at all as small as possible. In so far as funding may be required, it is to come from resolution and deposit guarantee funds that are subscribed by the banking industry in advance. Only if this fails or the funds run out would the taxpayer be called on. These same objections have been made to the creation of European Deposit Insurance Scheme (EDIS) (Stuchlik 2016). There is a clear moral hazard in any such form of insurance unless the premia paid in advance are adjusted to the relative risks. Reopening any of these debates would thus be sensitive. However, creating a banking union for the $\mathrm{EU}$ in the hope of getting round the unwillingness to address fiscal and structural problems in the euro area is clearly a contortion and could lead to perverse incentives when banks do get into difficulty.

The structure of the remainder of the paper is as follows: after an introduction to the problem as a whole in the next section, the paper deals with the incompleteness of the SSM and the missing features. 


\section{A preliminary}

In order to complete banking union, it is necessary to have a clear view of what such a union would eventually look like when completed. Presumably, it would operate like the banking system in the most efficient member states. In other words, savers could place their money with or borrow from any bank in the EU/EEA and have access to all transaction and other banking services irrespective of where the head office or branches were located or the currency they wished to deal in. ${ }^{10}$ There would be competition in interest rates and fees. ${ }^{11}$

Beyond that, there would be common rules for regulation and supervision. However, at that point there is a dilemma. Does a single market imply that there must be a single regulatory framework and a single supervisory system? If we look at the US, the answer is No. There is a degree of competition among regulators and supervisors. States still have their own regulators and supervisors, in addition to the system-wide federal agencies and federal legislation. Thus, the nature of banking permitted still varies, with Texas not permitting interstate branch banking, for example. Since it is not really possible to design the optimal rule system, an element of competition among rules is helpful, in that it provides an opportunity to discover which rules the participants in the market, whether providers, customers or intermediaries find best for their purposes.

The drawback of such a system is that it might result in a race to the bottom rather than a search for the highest quality system. There is some evidence in the US (Rosen 2001; Dell'Ariccia and Marquez 2006) that competition among regulators and supervisors has indeed resulted in a move towards the lowest standards, with the disproportionate incorporation in the state of Delaware and an equivalent focus on Luxembourg in the EU. Mayes, Nieto, and Wall (2011) took an agnostic view, simply suggesting that the way in which the US organised its market for banking services offered lessons for how the EU might structure its own system. But this was before the formulation of "banking union". Given the existence of "banking union", Mayes and Wood (2016) adopted a slightly different approach and suggested how the existing system might move towards a banking union whose description did not require inverted commas. However, both visions entail a common and simple institutional framework involving regulation, supervision and resolution.

The key difference between the US framework and that which is developing in the EU is resolution. The US has a history of bank failures, assisted by the structure of small local banks spread out across the country, which have difficulty diversifying their risks. Hence, there was a clear focus, even before the setting up of the Federal Deposit Insurance Corporation (FDIC) in 1935, on trying to resolve banks that failed in a way which had the minimum impact on society and particularly on ordinary depositors, for whom a bank collapse and the loss of their savings could be a terrible disaster. The FDIC became the resolution agency, to a large extent, because it was the institution exposed to the largest losses in the event of a failure and hence was the most powerful single creditor. Even without such a role, the courts would look to the largest creditor for guidance as to how an insolvency might be managed as agreement among the creditors is a key part of the solution.

In the EU on the other hand, not only in the main has the insurance of ordinary depositors been a much more recent concept but a resolution agency has not been so necessary, as banks in difficulty have typically been rescued rather than be allowed to sink into insolvency. Indeed, the first steps towards banking union involved the SSM rather than the SRM structure. ${ }^{12}$

A second major difference is that in the US, the treatment of the avoidance of banking problems and the resolution of any that do occur was a domestic issue until the global financial crisis. From the start of the single market, however, the EU has had to worry about a multi-country system, and one in 
which a bank in one jurisdiction might have a significant impact on people in another country, while the second country has little control over either the impending problem or its solution. The problem is not simply one of coordination and information among the home and host countries (Mayes and Vesala 2000) but of resolving the conflicts of interest that will inevitably arise as each country's primary concern is for its own financial stability, to minimise the impact on the real economy and to ensure that the burden is equitable and falls on those best able to bear it.

Before "banking union" was proposed, the obvious way to move forward was to build on existing institutions. For the crisis avoidance end of the spectrum and for the coordination of supervision, this implied going through CEBS (the Committee of European Banking Supervisors). Indeed, the formation of the European Banking Authority in 2011 seemed a step in this direction. It appeared a rather neat solution as the CEBS/ EBA was (and, pending Brexit, still is) based in London and therefore had the greatest chance of encouraging the UK authorities to participate in the scheme. Mayes, Nieto, and Wall (2011) saw this as incremental and starting with the large cross-border banking groups, very much in the way in which banking union has developed the task through the ECB.

At the other end of the process, if the US model had been followed, the EU/EEA resolution agency would have grown out of the deposit insurance system. Each member state had a deposit insurer or guarantor. However, these were and still are very different in character, ranging from institutions that simply pay out when requested to full-scale institutions that have a role in supervision and manage the resolution process. Some are private sector and others are public sector institutions. Trying to create a European Deposit Insurance Corporation (EDIC) from this would have been difficult (but not of course impossible). ${ }^{13} \mathrm{~A}$ European Forum of Deposit Insurers (EFDI) was formed in $2002 .{ }^{14}$ But, as its name implies, it is an association that is trying to help members work more closely together, set up with the encouragement of the European Commission. It operates across the whole of Europe although it has an EU Committee. In many respects, it is similar to IADI (the International Association of Deposit Insurers) which is one of the group of international standard setters organised through the Bank for International Settlements (BIS) in Basel. Gros and Schoenmaker (2014) follow this route in advocating a European Deposit Insurance and Resolution Agency (ED schemes, with pooled resources. They leave open whether smaller (non-systemic) banks could remain purely the responsibility of the national schemes. In principle, there is no reason why in due course the SRB could not be expanded to include the deposit insurance responsibilities for the banks that are directly supervised by the ECB and hence directly resolved by the SRB. With the proposal by the European Commission for a European Deposit Insurance Scheme (EDIS), EU arrangements would become more like the US with the expansion of the SRB into a Single Resolution and Deposit Insurance Board (European Commission 2015a; Stuchlik 2016).

\section{Completing the SSM and achieving resilience}

There is a large literature debating whether it is better to have the central bank as the supervisor of banks or whether to have an independent agency (see Elliott 2012; in the context of banking union). Not surprisingly, countries usually favour the status quo, and while Goodhart and Schoenmaker (1995) argue that the evidence is in favour of the central bank, this is disputed. At the heart of the debate is the trade-off between the central bank being better informed as a result of supervision and hence being able to run monetary policy better against the conflict of interest that can arise between inflation control and banking/financial stability. Moreover, there is the worry that the good reputation of the ECB in monetary policy will become tainted because of the inevitability of future banking problems and that the political consequences of bank resolutions will damage the ECB's 
independence. While Wall, Nieto, and Mayes (2011) argue in favour of a separate supervisor, now that the ECB has been assigned the role, it is probably not helpful to resurrect this debate given the lack of a consensus.

The problem remains that the SSM only covers the euro area, and other member states that decide to "join", 15 albeit under somewhat of a decision-making disadvantage from their not being represented on the Governing Council of the ECB. Secondly, the ECB can only be responsible for banks under Art 127(6) and not the whole of the financial sector. This thus precludes a total coverage of the financial sector or the following of the "twin peaks" model (Masciandaro and Quintyn 2015) where there is an independent supervisor of the whole sector. Since inadequacies in the supervision of the shadow banking sector were one of the important causes of the global financial crisis and work on the response of shadow banking sector to monetary policy shocks shows that it undermines monetary policy (at least in the US) (Xiao 2016), there are strong arguments for trying to complete the picture.

In so far as the SSM is incomplete, then the SRB and resolution, particularly of cross-border financial institutions, face a matching problem. The SRB will only get information from the ECB about the supervisory concerns it is informed about. Where other national supervisors are involved the SRB will need to seek information from them as well. Similarly, the degree to which national supervisors and resolution agencies have an obligation to act as the SRB wishes will be diluted. There will be more cases where resolution becomes a cooperative exercise and hence more difficult to execute with speed and certainty in a crisis.

The neatness of any answer is disturbed by Brexit. As things stand, the UK has some of the EU's most important and systemic banks and Europe's largest financial centre. That is not going to change in the short run, and there is a good case for trying to make sure that the UK remains in the single market for financial services both from the UK's and the rest of the EU's point of view. ${ }^{16}$ Indeed, it is particularly important for the EU as then they can exercise some element of control. Otherwise, the resolution of the UK's banks will remain the responsibility of the Bank of England and purely national concerns will come first. It is worth recalling Elliott's $(2012,4)$ very perspicacious remark:

A single supervisory regime for Europe would be good, but only if it has the right governance structure, so that all concerned can defend their viewpoints and their interests. Having a Eurozone entity effectively dictate overall EU policy is not appropriate and would ratchet up tensions with the U.K. sharply, especially given the often quite divergent views of finance and its regulation that are espoused by the U.K. as compared to the continent. In the worst case, tensions of this nature could help push the U.K. to exit the entire EU.

And he was not alone in that opinion. "I suspect that a banking union of some kind will be implemented, and soon. Otherwise, the eurozone banking system will collapse. But the consequences of such a step for Europe's great free-trade experiment could be serious, and, if not managed carefully, could lead to Britain's withdrawal." (Davies 2012).

Because recovery and resolution plans are not published, we will not know how credible the SRB's efforts are until they are put into practice. In any case, the chances are that the particular nature of any such crisis that does occur will come as a surprise. Otherwise, it would have been headed off before it reached crisis proportions. A simple answer would be that the large bulk of the problem is covered by the existing SSM/ SRM, and hence that requirements to "complete" banking union are largely unnecessary. This is particularly the case if one thinks that the preventative arm of the approach - the improved capital standards and the existence of extensive loss-absorbing capacity should mean that all the large banks can absorb the likely shocks that they might encounter in future. 
The effective capital buffers should be more than twice as large as their pre-crisis levels (Krimminger 2016) and have been calibrated to absorb the losses actually experienced by systemically important banks in the global financial crisis. Or to phrase it differently - if the banks that got into difficulty in the global financial crisis had then had the levels of capital and loss-absorbing capacity planned to be implemented by 2024, many of them would have been able to survive by "recovering", i.e. not actually needing state intervention, and all of the rest would have been able to go through a successful resolution using bailing in and related measures without any need for taxpayer funding.

So why bother to do anything more? The non-euro area countries are treated less than equal, and the EEA countries do not have the opportunity to hold even that diminished status of "close association" with the SSM.

The more important concern is that the SSM does not cover the whole of the activities of the major financial institutions. Expecting that the ECB would expand its remit to include insurance, nondepository institutions and shadow banking is probably a step too far. It would certainly encounter resistance from vested interests. However, given the experience in the US in the crisis, these excluded areas and the deficiencies in the ability to handle them could lie at the heart of future problems. An integrated system would imply major change, creating a new European institution that would be at least as large as the ECB (without supervision). Creating sectoral responsibility might be more plausible by upgrading ESMA and EIOPA. ${ }^{17}$

However, one part of the framework that could be under greatest challenge in the future is the whole system of payment and settlement. The rise of new technologies, such as the blockchain, is enabling people to transact directly without needing to go through banks and without the need for a central counterparty. Thus, the problem may not be so much that "banking union" needs completing, but that banking union is not a full solution to the problems of financial stability in the future.

\section{Completing the other parts of banking union}

The two pillars of banking union that are not yet complete are the constraints on the structure of EU banks suggested by the Liikanen report (HLEG 2012) and proposed in the draft directive of 24 January 2014 (European Commission 2014) and the implementation of the European Deposit Insurance System (European Commission 2015a). The implementation of the BRRD/SRR has altered the role of deposit insurance and to a large extent has removed the major problem revealed by the Icelandic banking crisis, namely that deposit insurance funds in small countries with large cross-border banks were inadequate to meet the claims in the event of failure. By making depositors preferred creditors and the deposit insurers "super-preferred" creditors, the chance of their incurring major losses in the failure of a large bank is now relatively small. ${ }^{18}$ Other creditors will be bailed in before them and are likely to be sufficiently large that they will absorb the total loss in most cases. ${ }^{19}$ Furthermore, any extraneous costs of resolution are likely to be met by the new resolution funds, including the SRF when it reaches full capacity in $2024 .^{20}$

Demands on deposit insurance funds are likely to be made mainly for the resolution of smaller banks that can be allowed to stop operating in the event of failure. The key parts of the deposit insurance directive (European Commission 2015a) are hence that in future all deposit insurers should be funded (art 41), so there is no problem in countries where the sovereign is heavily indebted and cannot bail out the deposit insurer. ${ }^{21}$ And that a degree of reinsurance be introduced so that the funds can help each other (art 41), thus making the funds more effective, except when the problem is ubiquitous. 
The debate on the importance of the structural measures that are needed to improve resolvability has changed tack in the last few years. There is now a possibility that the Dodd-Frank Act will be amended, if the remarks of the incoming President in the election campaign (Egan 2017) are followed through, and this may well include the so-called Volcker Rule that requires the separation of "banking" and "trading" activities. The inverted commas are necessary because there is considerable debate over where the borderline between the two should lie and the main proposals and legislation on the topic in the US, ${ }^{22}$ UK, ${ }^{23}$ Germany, ${ }^{24}$ France, ${ }^{25}$ Liikanen ${ }^{26}$ and the EU draft directive ${ }^{27}$ all differ.

While "completing banking union" could be taken to imply that the draft directive should be passed into law, this implies that the legislation is necessary for the proper functioning of the union. The alternative argument is that what is in place at present, even though it varies across the EU, is sufficient to ensure the resolvability of the main banks. Indeed, the SRB has the power to demand changes in structure if it feels those are necessary for resolvability (SRR art 10 (11) (d) - (h) sets out what it can demand and art 10 (12) gives it the power over national authorities). There is a debate over what the main point of the separation of banking and trading activities is. If it is primarily defensive in that banks need to be protected from the volatility of trading activities and the size of the ensuing losses, then clearly the separation is necessary. If the reason for division is simply to ensure resolvability but resolvability is thought possible with existing structures, then the change is not required. Indeed, the argument of many of the opponents of division is that trading on average offers a higher return than banking and hence helps with the capitalisation and profitability of the group as a whole, thereby strengthening the banking operation. ${ }^{28}$ Furthermore, the diversification of the group helps offset problems when the banking side of the business is not doing so well.

It is really up to the SRB to decide whether the risks and the resolvability are acceptable. Division or the lack of it is only an element of "banking union" in so far as the lack of a common position matters.

\section{The wider agenda}

"Banking union" in the EU/EEA is clearly incomplete. While it is possible that the deposit insurance proposals may be enacted in the reasonable future and the funding and capital buffers should all be in place by 2024, it is likely that the union will remain incomplete, at least until the next major crisis when the deficiencies that matter are revealed. This is largely because the institutional changes required could well involve treaty changes and would disturb institutional changes that are themselves quite recent.

The question is: Does this matter? If this incomplete system is going to function satisfactorily, then the effort of struggling for the neatness of completion is not justified. The difficulty with answering this question is that to quite a large extent it depends on how the system will function in practice and not about how it could possibly malfunction in theory. This article focuses on two aspects of this incompleteness:

(1) The fact that the SSM/ECB does not cover the whole of the EU/EEA and the financial system

(2) Some of the structural requirements have not been completed, such as the follow up to the Liikanen report

While the lack of total coverage in terms of member states will in part be dealt with by the exit of the UK, it is a combination of the structure of the financial system and the recovery/resolution regime that will determine the outcome. With the UK choosing to ring fence banking operations and apply the single point of entry approach to resolution, ${ }^{29}$ the difficulties from its involvement are being dealt 
with irrespective of Brexit. It thus depends upon what happens with the rest of cross-border banking, where there is more reliance on cooperation across the authorities in the different countries. Small countries that are not in the SRM, or even those that are to some extent, and have an extensive part of their banking system run by branches and subsidiaries of foreign banks will be at a bargaining disadvantage over the resolution and recovery plans for those foreign banks. If they are not heavily indebted, they may be able to overcome this disadvantage by using taxpayers' money to keep the financial system functioning well.

Ironically, because the structure of the main banks is very far from what one would expect from a true banking union, where operations would run across the whole EU through a unified structure, the problem of handling them in the event of difficulty is considerably easier. One response to the global financial crisis has been for the main banks to become rather more national and less cross-border (with some specific exceptions such as Santander). That trend cannot be relied on for the future. One very positive sign is the announcement by Nordea on 6 September 2017 that it intends to move its domicile from Sweden to Finland, thus moving into the SSM. ${ }^{30}$

While pragmatic decisions have been taken over appropriate structures for banks at a national level, the resolvability of the largest banks is still to be fully worked through by the SRB and the other resolution authorities. However, the stability of banking union will also depend on the stability of the rest of the financial system, especially shadow banking, and hence on how well that is supervised. Thus, "banking union" is a major step towards a more stable and resilient financial system. In normal times, it will function well and is likely to handle the occasional failure of smaller institutions efficiently and effectively. But the SRB's main function is to handle major crises. It thus only gets tested properly in extreme events which stress tests and other "war games" cannot simulate effectively. The vulnerabilities from the incomplete union and the untested tools will remain. The likely result will therefore always be debatable.

\section{Notes}

1. This includes the "Single Rulebook" and related harmonisation measures by the European Banking Authority (EBA) which seek to set common standards across the whole of the EU/ EEA and not just minimum standards as tended to be the case previously.

2. Regulation (EU) No 806/2014 of the European Parliament and of the Council establishing uniform rules and a uniform procedure for the resolution of credit institutions and certain investment firms in the framework of a Single Resolution Mechanism and a Single Resolution Fund and amending Regulation (EU) No 1093/2010, available at http://eur-lex.europa.eu/legal-content/EN/TXT/ PDF/?uri=CELEX:32014R0806\&from=EN (last accessed 12 November 2015), labelled SRR hereafter.

3. It was felt necessary to buttress the SRF by adding an intergovernmental agreement to the SRR (Council of the European Union, Agreement on the transfer and mutualisation of contributions to the Single Resolution Fund, 8457/14, available at http://register.consilium.europa.eu/doc/srv?l=EN\&f =ST\%208457\%202014\%20INIT.

4. Howarth and Quaglia (2016) provide a helpful exposition of the process of agreement and how the views of the different protagonists were taken into account in the compromise.

5. The European Commission (2015b) and the Five Presidents' Report (Juncker et al. 2015) suggest ways forward. 
6. European Commission (2014).

7. See HLEG (2012) for the report.

8. Stuchlik (2016) gives a clear exposition of what is intended (European Commission, 2015a) and its progress through the European Parliament.

9. The ECB acts as Lender of Last Resort in the traditional sense of providing emergency liquidity to all solvent banks when markets dry up and has done this extensively since 2008; see chapter 1 in Castañeda, Mayes, and Wood (2016). Emergency Liquidity Assistance to individual banks is provided by the national central banks, with the ECB's approval in the case of the euro area. The lacuna is where a small national central bank cannot provide adequate support for a large cross-border institution, as was the case in Iceland. Lending to enable recapitalisation and restructuring via the European Stability Mechanism (ESM) only helps if the loan can be repaid, as in the case of Spain in 2013. Traditionally, such loans are either paid back from the insolvency if the bank fails or from the profits or refinancing if the bank recovers successfully. The ECB only offers euro financing, so some recoveries may require actions outside its immediate control.

10. There has been no shortage of direct advice for EU decision-makers on the appropriate form for "banking union" and the various short contributions to Beck (2012) offered a wide range of thoughtful advice. See also Elliott (2012).

11. There is an immediate problem in this ideal picture as, in the main, banking in the EU/EEA has strong divisions along national lines. Even where banks operate in more than one member state, these operations are separate. Thus, even though you may be a long-standing customer of Nordea in Finland, to have access to full banking facilities in Norway with the same bank, you have to open a new account and go through the normal "know your customer" requirements as if your Finnish account did not exist. (Although Nordea ATMs in Norway will automatically give instructions in Finnish if you insert a Finnish Nordea card.).

12. Goodhart (2012) emphasised the importance of taking the two parts together, and Schoenmaker (2012) went even further in arguing that banking union should be constructed from the opposite direction, starting with the resolution mechanism and then working out what that implied for the structure of supervision and regulation. The argument for starting with the SSM is that unless one can agree how adequate supervision across the $\mathrm{EU}$ is to be established then no one will be willing to discuss a resolution system where one country may in effect be bailing out another.

13. As the EDIS proposal mentioned below illustrates, it is possible to run an agency with different component schemes as is illustrated by most insurance companies. The possibility of setting up an EDIC was suggested by Wall, Nieto, and Mayes (2011) simply because the US template existed and could be followed.

\section{See http://www.efdi.eu/efdi.}

15. The phrase in the SSM Regulation (art 7) is "in close cooperation" (European Council 2013).

16. There is of course considerable doubt over whether that will happen given the UK government's present stance (May 2017), but many think that in the longer term the UK's position in the single market for financial services will effectively be maintained (Leigh 2017).

17. Indeed, this is something which may happen if ESMA becomes the centre of "capital markets union". 
18. The main circumstance where deposit insurers are likely to have to contribute to the resolution is when creditors of the same priority are bailed in and hence they become liable, along with uninsured depositors, for the (proportionate) amount that depositors would have had to contribute to the resolution had they not been insured (Directive 2014/59/EU art 109). This is an application of the pari passu principle.

19. In simulations of who would have been bailed in had the BRRD been applied to the failure of banks in the EU in 2008-10, Conlon and Cotter (2016) find that in almost all cases it would not have been necessary to bail-in senior creditors. In a similar exercise looking at the 26 largest banks in the euro area, Hüser et al. (2017) find that, for the largest shock they consider, 7 of the 26 banks would require some degree of bail-in of deposits to return to being well capitalised.

20. There has been an extensive debate about whether the SRF is large enough to handle all eventualities. Clearly, there can be circumstances that could require recourse to back up funding, but outside major crises this is unlikely if the calculations of De Groen and Gros (2015) are to be believed.

21. In the Nordic crises, the insurance funds became depleted and required replenishing or replacing by the state (Mayes 2017).

22. § 619 (12 U.S.C. § 1851) of the Dodd-Frank Wall Street Reform and Consumer Protection Act.

23. Independent Commission on Banking (2013).

24. Gesetz zur Abschirmung von Risiken und zur Planung der Sanierung und Abwicklung von Keditinstituten und Finanz Gruppen, 7 August 2013, Bundesgesetzblatt Part I, p. 3090.

25. Loi no. 2013-672 du 26 juillet 2013 de separation et de regulation des activités bancaires, Journal Officiel de la Républic Française no. 0173 du 27 juillet 2013, p. 12,530.

26. HLEG (2012).

27. European Commission (2014).

28. See Binder (2014) inter alia for a review of the arguments.

29. With single point of entry, the home country resolves the problems for the entire cross-border banking group by ensuring that the parent company becomes adequately capitalised again and hence that all of the subsidiaries in host countries that might be thought systemically important can also continue.

30. https://www.nordea.com/en/press-and-news/news-and-press-releases/press-releases/2017/0906-16h50-the-nordea-bank-ab-publ-board-of-directors-initiates-a-re-domiciliation-of-the-parentcompany-to-finland.html. 


\section{References}

Beck, T. 2012. Banking Union for Europe: Risks and Challenges. London: CEPR.

Binder, J.-H. 2014. "To Ring-Fence or Not, and How? Strategic Questions for Post-Crisis Banking Reform in Europe." Accessed February 2, 2017. https://ssrn.com/abstract=2543860

Castañeda, J. E., D. G. Mayes, and G. E. Wood. 2016. European Banking Union: Prospects and Challenges. Abingdon: Routledge.

Conlon, T., and J. Cotter. 2016. "Euro Area Bank Resolution and Bail-in: Intervention, Triggers and Writedown." In European Banking Union: Prospects and Challenges, edited by J. E. Castañeda, D. G. Mayes and G. E. Wood, 78-99. Abingdon: Routledge.

Davies, H. 2012. "European Banking Union Raises Unanswerable Questions." Accessed February 6, 2017. https://www.theguardian.com/business/economics-blog/2012/jun/29/eurozone-banking-unio n-questions.

De Groen, W. P. and Gros, D. 2015. "The Single Resolution Fund: How much is needed?." Accessed June 26, 2017. http://voxeu.org/article/size-single-resolution-fund.

Dell'Ariccia, G., and R. Marquez. 2006. "Competition Among Regulators and Credit Market Integration." Journal of Financial Economics 79: 401-430.

Egan, M. 2017. "Trump Pledges to 'Do a Big Number' on Dodd-Frank Wall Street Reform." CNN Money, 30 January. Accessed February 2, 2017. http://money.cnn.com/2017/01/30/investing/dodd-franktrump-regulation-banks/.

Elliott, D. 2012. "Key Issues on European Banking Union: Trade-Offs and Some Recommendations." Global Economy and Development Working Paper 52, Brookings.

European Commission. 2014. "Proposal for a Regulation of the European Parliament and of the Council on Structural Measures Improving the Resilience of EU Credit Institutions". Accessed October 30, 2014. http://eur-lex.europa.eu/legal-content/EN/TXT/?uri=CELEX:52014PC0043.

European Commission. 2015a "Proposal for a Regulation of the European Parliament and of the Council amending Regulation (EU) 806/2014 in order to establish a European Deposit Insurance Scheme". Accessed February 2, 2015. http://eur-lex.europa.eu/legal-content/EN/TXT/?uri=CE LEX:52015PC0586.

European Commission. 2015b. "Towards the Completion of the Banking Union." Communication from the Commission $\operatorname{COM(2015)} 587$ final, 24 November. Accessed February 4, 2017. http://data. consilium.europa.eu/doc/document/ST-14650-2015-INIT/en/pdf (last).

European Council. 2013. "Council Regulation (EU) 1024/2013 of 15 October 2013 conferring specific tasks on the European Central bank concerning policies relating to the prudential supervision of credit institutions". Accessed February 2, 2017. http://eur-lex.europa.eu/LexUriServ/LexUriServ.do?uri=OJ :L:2013:287:0063:0089:EN:PDF.

Goodhart, C. 2012. "Funding Arrangements and Burden Sharing in Banking Union." In Banking Union for Europe: Risks and Challenges, edited by T. Beck, 103-112. London: CEPR.

Goodhart, C., and D. Schoenmaker. 1995. "Should the Functions of Monetary Policy and Banking Supervision Be Separated?" Oxford Economic Papers 47 (4): 539-560. 
Gros, D., and D. Schoenmaker. 2014. "European Deposit Insurance and Resolution in the Banking Union." JCMS: Journal of Common Market Studies 52 (3): 529-546.

HLEG 2012. "High-Level Expert Group on Reforming the Structure of the EU Banking Sector." Accessed October 30, 2014. https://ec.europa.eu/info/system/files/liikanen-report-02102012 en.pdf.

Howarth, D., and L. Quaglia. 2013. "Banking Union as Holy Grail: Rebuilding the Single Market in Financial Services, Stabilizing Europe's Banks and 'Completing' Economic and Monetary Union." JCMS: Journal of Common Market Studies 51 (1): 103-123.

Howarth, D and Quaglia, L. 2014. "The Steep Road to European Banking Union: Constructing the Single Resolution Mechanism." Journal of Common Market Studies 52 (annual review): 125-140.

Howarth, D., and L. Quaglia. 2016. The Political Economy of Banking Union. Oxford: Oxford University Press.

Hüser, A-C., Halaj, G., Kok, C., Perales, C. and van der Kraaij, A. 2017. "The systemic implications of bail-in: A multi-layered network approach." ECB Working Paper no. 2010.

Independent Commission on Banking. 2013. "The Vickers Report." Accessed October 31, 2014. Http://www.parliament.uk/business/publications/research/briefing-papers/SN06171.pdf

Juncker, J.-C., Tusk, D., Dijsselbloem, J., Draghi M. and Schulz, M. 2015. "Completing Economic and Monetary Union" (The Five Presidents' Report). Accessed February 11, 2017. https://ec.europa.eu/ priorities/sites/beta-political/files/5-presidents-report en.pdf

Krimminger, M. 2016. "Shadows and Mirrors: The Role of Debt in the Developing Resolution Strategies in the US, UK and European Union." In European Banking Union: Prospects and Challenges, edited by J. E. Castañeda, D. G. Mayes and G. E. Wood, 156-183. Abingdon: Routledge.

Lastra, R. M. 2016. "Lender of Last Resort and Banking Union." In European Banking Union: Prospects and Challenges, edited by J. E. Castañeda, D. G. Mayes and G. E. Wood, 109- 128. Abingdon: Routledge.

Leigh, M. 2017. "Remarks at 'The EU in a Post-Brexit World'." Seminar National Centre for Research on Europe University of Canterbury. Accessed February 2, 2017. https://www.youtu be.com/watch?v=oUV_pxf3ef8

Masciandaro, D., and M. Quintyn. 2015. "The Governance of Financial Supervision: Recent Developments." Journal of Economic Surveys 30 (5): 982-1006.

May, T. 2017. "A global Britain" Speech at Lancaster House, 17 January. Accessed February 2, 2017. http://www.independent.co.uk/news/uk/home-news/full-text-theresa-may-brexit-speechglobalbritain-eu-european-union-latest-a7531361.html

Mayes, D. G. 2017. "Top down Restructuring of Markets and Institutions: The Nordic Banking Crises." Journal of Banking Regulation 18 (3): 213-232. doi:10.1057/s41261-016-0006-z.

Mayes, D. G., and J. Vesala. 2000. "On the Problems of Home Country Control." Current Economics and Politics of Europe 10 (1): 1-25.

Mayes, D. G., and G. E. Wood. 2016. "Banking Regulation: Starting over." In Breaking up is Hard to Do: Britain and Europe's Dysfunctional Relationship, edited by P. Minford and J. R. Shackleton, 229-252. Westminster: The Institute of Economic Affairs. 
Mayes, D. G., Nieto, M. J. and Wall, L. D. 2011. "A Deposit Insurance Model for Europe." Paper presented at the EUSA biennial meeting, Boston, MA. Accessed March 25, 2015. http://www.euce.org/eusa/2011/papers/12d mayes.pdf

Rosen, R. J. 2001. "Do Regulators Search for the Quiet Life? The Relationship between Regulators and the Regulated in Banking." Federal Reserve Bank of Chicago Working Paper WP2001-05.

Schäfer, D. 2016. "Explaining the Creation of the EU Banking Union: The Stability Culture, the Vicious Circle, and the Limits of Power and Interests." Mimeo LSE. Accessed February 5, 2017. http://aei.pitt.edu/79657/1/Schafer.pdf.

Schoenmaker, D. 2012. "Banking Union: Where We're Going Wrong." In Banking Union for Europe: Risks and Challenges, edited by T. Beck, 95-102. London: CEPR.

Stuchlik, A. 2016. "European Deposit Insurance Scheme: Completing the Banking Union." European Parliamentary Research Service Briefing on EU legislation in progress 14 March. Accessed February 4, 2017. http://www.europarl.europa.eu/RegData/etudes/BRIE/2016/579090/EPRS BRI(2016)579090 EN.pdf

Wall, L. D., Nieto, M. J. and Mayes, D. G. 2011. "Creating an EU-Level Supervisor for CrossBorder Banking Groups: Issues Raised by the U.S. Experience with Dual Banking." FRB Atlanta Working Paper 2011-06, Federal Reserve Bank of Atlanta.

Xiao, K. 2016. "How Does Monetary Policy Affect Shadow Bank Money Creation." Mimeo: University of British Columbia. Accessed February 2, 2017. http://www.cicfconf.org/sites/default/files/paper 296.pdf 